\title{
Inappropriate antidiuretic hormone syndrome presenting as ectopic antidiuretic hormone- secreting gastric adenocarcinoma: a case report
}

Kyungo Hwang ${ }^{1}$, Dae-Hong Jeon ${ }^{1}$, Ha Nee Jang ${ }^{1}$, Eun Jin Bae ${ }^{1}$, Jong Sil Lee ${ }^{2}$, Hyun Seop Cho ${ }^{1}$, Se-Ho Chang ${ }^{1,3}$ and Dong Jun Park ${ }^{1,3^{*}}$

\begin{abstract}
Introduction: Although the syndrome of inappropriate antidiuretic hormone has connection with various malignant tumors, there are few reports associated with advanced gastric cancer.

Case presentation: We describe the case of a 63-year-old Korean male with inappropriate antidiuretic hormone syndrome due to an ectopic antidiuretic hormone-producing advanced gastric adenocarcinoma manifested with overt serum hypo-osmolar hyponatremia and high urinary sodium concentrations. His adrenal, thyroidal, and renal functioning were normal, and the hyponatremia improved following removal of the tumor. The cancer cells were immunostained and found to be positive for the antidiuretic hormone. To our knowledge, this is the first report of an antidiuretic hormone-secreting advanced gastric adenocarcinoma associated with the syndrome of inappropriate antidiuretic hormone, showing cancer cells immunostained for the antidiuretic hormone.

Conclusions: Although a strong relationship between gastric cancer and the syndrome of inappropriate antidiuretic hormone remains to be established, we suggest that gastric cancer could be included as a differential diagnosis of cancer that is associated with the syndrome of antidiuretic hormone.
\end{abstract}

Keywords: ADH, Gastric adenocarcinoma, Hyponatremia

\section{Introduction}

The syndrome of inappropriate antidiuretic hormone (SIADH) is characterized by the excessive release of serum antidiuretic hormone (ADH) relative to serum osmolality. It typically results in excessive water reabsorption in the collecting ducts and hyponatremia. $\mathrm{SIADH}$ is frequently found in patients diagnosed with a variety of malignancies, including lung, brain, bladder, duodenum, pancreas, prostate, and head and neck cancer, as well as lymphoma, leukemia, mesothelioma, and thymoma $[1,2]$. However, there are very few reports of SIADH associated with advanced gastric cancer (AGC) [3-5].

\footnotetext{
* Correspondence: drpdj@korea.com

'Department of Internal Medicine, Gyeongsang National University, College of Medicine, 816 Beongil 15 Jinju-daero, Jinju, South Korea

${ }^{3}$ Institute of Health Science, Gyeongsang National University, College of

Medicine, 816 Beongil 15 Jinju-daero, Jinju, South Korea

Full list of author information is available at the end of the article
}

\section{Case presentation}

A 63-year-old Korean male was admitted to our hospital with anorexia, generalized weakness, and melena that began three days prior to admission. The patient had been admitted to the emergency room three months prior due to nausea and vomiting. His serum sodium level was $114 \mathrm{mEq} / \mathrm{L}$, osmolality was $250 \mathrm{mOsm} / \mathrm{kg}$, and uric acid was $2.9 \mathrm{mg} / \mathrm{dL}$. Tests revealed urine osmolality and sodium to be $390 \mathrm{mOsm} / \mathrm{kg}$ and $57 \mathrm{mEq} / \mathrm{L}$, respectively. These laboratory results were consistent with SIADH. Despite a recommendation for further evaluation, the patient refused to be admitted to the hospital. He was subsequently discharged after his symptoms subsided and his sodium levels were restored to $122 \mathrm{mEq} / \mathrm{L}$ following an infusion of $3 \%$ saline.

Upon admission, the patient did not display signs of dehydration or over-hydration. The patient did not have an underlying disease, such as diabetes, hypertension, chronic hepatitis, renal disease, or chronic lung disease, 
and was not taking any medication. He did not have a contributing family history. His blood pressure was $130 / 80 \mathrm{mmHg}$, his pulse rate was 78 beats per minute, and his body temperature was $36.7^{\circ} \mathrm{C}$. His physical and neurological examinations were normal. Laboratory tests revealed the following: hemoglobin $13.4 \mathrm{~g} / \mathrm{dL}$, platelets $159 \times 10^{3} / \mathrm{mm}^{3}$, white blood cells $6,700 / \mathrm{mm}^{3}$ (30\% neutrophils, $52 \%$ lymphocytes), serum sodium $109 \mathrm{mEq} / \mathrm{L}$, potassium $3.6 \mathrm{mEq} / \mathrm{L}$, chloride $71.4 \mathrm{mEq} / \mathrm{L}$, osmolality $223 \mathrm{mOsm} / \mathrm{kg}$, uric acid $2.4 \mathrm{mg} / \mathrm{dL}$, alkaline phosphatase (ALP) $110 \mathrm{U} / \mathrm{L}$, aspartate transaminase (AST) 23U/L, alanine transaminase (ALT) $29 \mathrm{U} / \mathrm{L}$, total protein $7.3 \mathrm{~g} / \mathrm{dL}$, albumin $3.9 \mathrm{~g} / \mathrm{dL}$, creatinine $0.9 \mathrm{mg} / \mathrm{dL}$, urine sodium $52.4 \mathrm{mEq} / \mathrm{L}$, and osmolality $345 \mathrm{mOsm} / \mathrm{kg}$. His serum sodium level increased to $121 \mathrm{mEq} / \mathrm{L}$ following a twoday infusion of $3 \%$ saline, and his plasma ADH level (Kit; BÜHLMANN, method: RIA (radio-immunoassay), Schönenbuch, Switzerland) was $11.18 \mathrm{pg} / \mathrm{mL}$ (0 to 6.7 ) at that time. Thyroid function tests revealed his thyroidstimulating hormone (TSH) level to be $1.02 \mu \mathrm{U} / \mathrm{mL}(0.27$ to 4.2 ), free $\mathrm{T} 4$ to be $1.28 \mu \mathrm{U} / \mathrm{mL}$ (0.93 to 1.70$)$, and a total T3 of $91.02 \mu \mathrm{U} / \mathrm{mL}$ (80 to 200). An adrenocorticotropic hormone $(\mathrm{ACTH})$ stimulation test demonstrated that his basal cortisol level was $22.64 \mu \mathrm{g} / \mathrm{dL}$. Moreover, his cortisol level was $27.89 \mu \mathrm{g} / \mathrm{dL}$ at 30 minutes following $\mathrm{ACTH}$ administration $(250 \mu \mathrm{g})$, and $33.73 \mu \mathrm{g} / \mathrm{dL}$ at 60 minutes after ACTH administration. His prostate-specific antigen (PSA) level was $1.80 \mathrm{ng} / \mathrm{mL}$. His serum sodium level partially recovered to $127 \mathrm{mEq} / \mathrm{L}$ by water restriction prior to surgery.

A gastroendoscopy procedure revealed an ulceroinfiltrative lesion on the lesser curvature of the upper high body, with irregular margins and a diameter of $2.5 \times 2.5 \mathrm{~cm}$ (Figure 1). Bleeding was found to be present at the center of the ulceration. A biopsy revealed a moderately

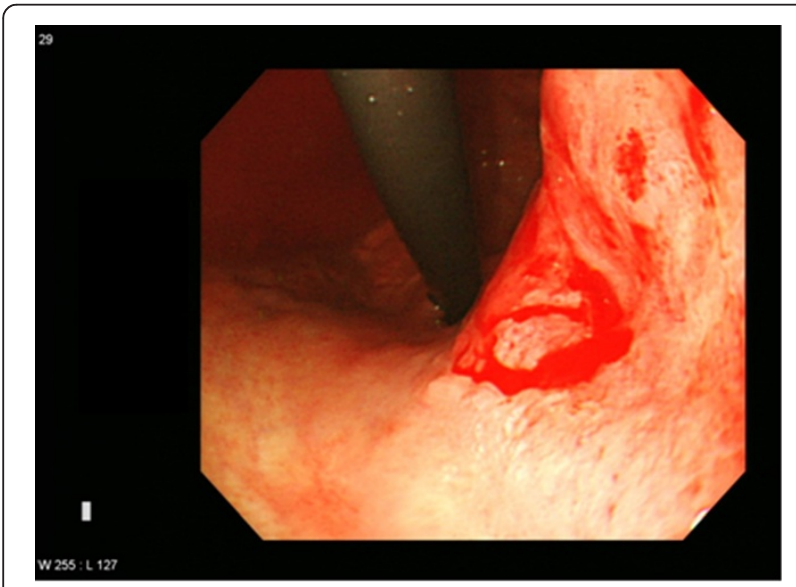

Figure 1 A gastrofibroscopy shows an ulceroinfiltrative lesion with active oozing bleeding. The lesion was roughly $2.5 \times 2.5 \mathrm{~cm}$ in size and located at the center of a defective ulcer base of the lesser curvature of the high body. differentiated adenocarcinoma. A computed tomography (CT) scan revealed a thickened wall on the lesser curvature of the high body (Figure 2). A laparoscopic total gastrectomy and Roux-en Y esophago-jejunostomy was performed. Tumor cells were found to have infiltrated the subserosa and had metastasized to a single perigastric lymph node, resulting in stage T3N1M0 cancer. His sodium level and ADH level normalized to $135 \mathrm{mEq} / \mathrm{L}$ and $5.9 \mathrm{pg} / \mathrm{mL}$ respectively, three weeks following the surgery (Table 1). Retrospective immunohistochemical staining of the cancer cells were positive for the $\mathrm{ADH}$ protein (H-300, Santa Cruz Biotechnology, Santa Cruz, CA, United States) (Figure 3a). No staining was detected on the normal gastric cells (Figure $3 b$ ). He died due to cancer progression 1.6 years later after diagnosis despite operation and chemotherapy.

\section{Discussion}

Our case report details a patient with SIADH associated with an AGC. This was confirmed by 1) hypo-osmolar hyponatremia, hypouricemia, high urinary sodium concentration and concentrated urine; 2) normal adrenal, thyroid, and renal function; 3) inappropriate secretion of ADH under hyponatremia; 4) positive immunostaining of the cancer cells with an anti-ADH antibody; 5) a full restoration of serum sodium concentration and $\mathrm{ADH}$ levels following the removal of the tumor. To the best of our knowledge, this is the first report of AGC associated with SIADH that was histologically confirmed by antiADH immunostaining of the tumor cells.

SIADH is often regarded as a diagnosis of exclusions. First, adrenal and thyroid diseases with associated hyponatremia should be excluded. Various medical conditions should be considered in relation to SIADH, including [2]: 1) ectopic secretion of $\mathrm{ADH}$ (released from tumor tissue,

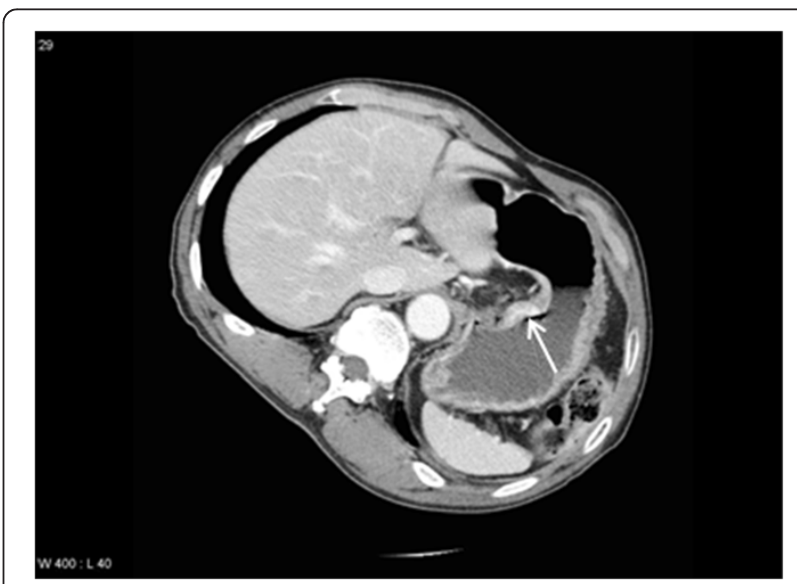

Figure 2 An axial computational tomography scan of the lesser curvature of the high body in the stomach. The fat plane is preserved. No lymphadenopathy is seen. Scan shows thickening (arrow) and mucosal enhancement. 
Table 1 Serum and urinary laboratory data after admission and post-operation

\begin{tabular}{|c|c|c|c|c|c|c|}
\hline & $\begin{array}{c}\text { Admission } \\
\text { day }\end{array}$ & $\begin{array}{c}\text { Admission } \\
\text { 3rd day }\end{array}$ & $\begin{array}{l}\text { Post OP } \\
\text { 1st day }\end{array}$ & $\begin{array}{l}\text { Post OP } \\
\text { 5th day }\end{array}$ & $\begin{array}{l}\text { Post OP } \\
\text { 12th day }\end{array}$ & $\begin{array}{l}\text { Three weeks } \\
\text { after OP }\end{array}$ \\
\hline Serum sodium (mEq/L) & 109 & 121 & 128 & 131 & 134 & 135 \\
\hline Serum osmolality (mOsm/kg) & 223 & 250 & 264 & 276 & NA & NA \\
\hline Urine sodium (mEq/L) & 52.4 & 76.3 & 73.2 & NA & NA & NA \\
\hline Urine osmolality (mOsm/kg) & 325 & 356 & 337 & NA & NA & NA \\
\hline Plasma ADH level (pg/mL) & NA & 11.18 & NA & NA & NA & 5.9 \\
\hline
\end{tabular}

$\mathrm{ADH}$, antidiuretic hormone; $\mathrm{NA}$, not available; $\mathrm{OP}$, operation.

infections, or conditions with altered intrathoracic pressure, such as with a pneumothorax or status asthmaticus); 2) increased hypothalamic production of ADH-like substances associated with neurological disorders (infections, Guillain-Barre syndrome, and brain tumors); 3) medications (cytotoxic agents, carbamazepine, chlorpropamide, clofibrate, narcotics, and sulfonylurea); and 4) administration of exogenous $\mathrm{ADH}$ or oxytocin. Excluding gastric cancer, several conditions were ruled out in the present case by verifying hormone levels and conducting a thorough medical history, physical examination, and laboratory and radiological tests. Importantly, his hyponatremia and elevated serum ADH levels improved following the removal of the tumor, indicating that the hyponatremia was associated with the ADH-secreting cancer cells.

Excessive ADH secretion is often found in tumors with ectopic hormone production. Three clinical conditions are necessary for a tumor with ectopic ADH production [6]. These criteria include SIADH as a clinical symptom of hormone recovery of hyponatremia after removal of the tumor. The hyponatremia present in our patient was due to ADH-secreting cancer cells.

A previous study including a large number of SIADH patients reported that SIADH occurs in 3\% of patients with head and neck cancer, $0.7 \%$ of patients with nonsmall-cell lung cancer, and $15 \%$ of patients with smallcell lung cancer [1]. The relationship between SIADH and gastric cancer, however, is not well established. Anti-ADH antibodies have not been used to detect ADH in cancer tissue in the three cases of gastric cancer that have been reported since 1990. Here, we demonstrated hyponatremia with ADH-stained gastric cancer cells. Although the rate of gastric cancer is decreasing, it is still the most common type of cancer in Korea. According to the Korean Ministry of Health and Welfare 2010 report, stomach cancer is the leading cause of cancer with an incidence of $15.7 \%$. The use of a gastric endoscopy is difficult to enforce due to the high incidence of stomach cancer. However, the lower incidence of hyponatremia in our case describes a patient who initially presented with symptoms of nausea and vomiting associated with hyponatremia, which lead to a diagnosis of AGC three months later.

\section{Conclusions}

Although a strong relationship between gastric cancer and SIADH remains to be established, we suggest that gastric cancer could be included as a differential diagnosis of cancer that is associated with SIADH.

\section{Consent}

Written informed consent was obtained from the patient's next-of-kin for publication of this case report and accompanying images. A copy of the written consent is available for review by the Editor-in-Chief of this journal.
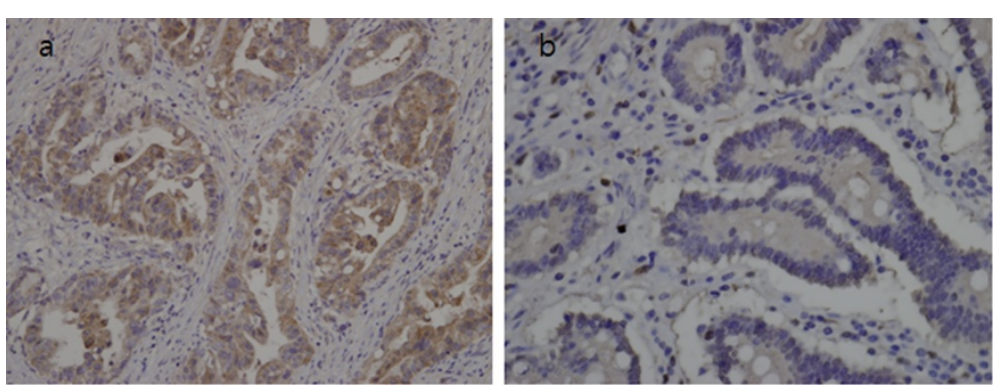

Figure 3 Immunostainings of cancer and normal gastric cells. (a) Cancer cells positive for the antidiuretic hormone protein $(\times 200$ magnification). (b) Normal gastric cells negative for the antidiuretic hormone protein (×200 magnification). 


\section{Abbreviations}

ACTH: adrenocorticotropic hormone; ADH: antidiuretic hormone:

AGC: advanced gastric cancer; CT: computational tomography;

PSA: prostate-specific hormone; SIADH: syndrome of inappropriate

antidiuretic hormone; TSH: thyroid stimulating hormone.

\section{Competing interests}

The authors declare that they have no competing interests.

\section{Authors' contributions}

All authors read and approved the final manuscript. HK wrote and edited the report. JDH, JHN, BEJ, CHS, CSH, and PDJ participated in writing and editing the manuscript. LJS helped to describe and interpret our all figures.

All authors read and approved the final manuscript.

\section{Author details}

'Department of Internal Medicine, Gyeongsang National University, College of Medicine, 816 Beongil 15 Jinju-daero, Jinju, South Korea. ${ }^{2}$ Department of Pathology, Gyeongsang National University, College of Medicine, 816 Beongil 15 Jinju-daero, Jinju, South Korea. ${ }^{3}$ Institute of Health Science, Gyeongsang National University, College of Medicine, 816 Beongil 15 Jinju-daero, Jinju, South Korea.

Received: 11 October 2013 Accepted: 26 March 2014

Published: 12 June 2014

\section{References}

1. Sorensen JB, Andersen MK, Hansen HH: Syndrome of inappropriate secretion of antidiuretic hormone (SIADH) in malignant disease. J Intern Med 1995, 238:97-110.

2. Nakayama S, Yokote T, Kobayashi K, Hirata Y, Akioka T, Miyoshi T, Takubo T, Tsuji M, Hanafusa T: Syndrome of inappropriate antidiuretic hormone secretion associated with acute myeloid leukemia with multilineage dysplasia. Endocrine 2009, 35:290-292.

3. Wall BM, Crofton JT, Share L, Cooke CR: Chronic hyponatremia due to resetting of the osmostat in a patient with gastric carcinoma. Am J Med 1992, 93:223-228.

4. Mouallem M, Ela N, Segal-Lieberman G: Meningeal carcinomatosis and syndrome of inappropriate antidiuretic hormone in a patient with metastatic carcinoma of the stomach. South Med J 1998, 91:1076-1078.

5. Alfa-Wali M, Clark GW, Bowrey DJ: A case of gastric carcinoma and the syndrome of inappropriate antidiuretic hormone secretion (SIADH). Surgeon 2007, 5:58-59.

6. Yamazaki T, Suzuki H, Tobe T, Sekita N, Kito H, Ichikawa T, Akakura K, Igarashi T, Ito H: Prostate adenocarcinoma producing syndrome of inappropriate secretion of antidiuretic hormone. Int J Urol 2001, 8:513-516.

doi:10.1186/1752-1947-8-185

Cite this article as: Hwang et al: Inappropriate antidiuretic hormone syndrome presenting as ectopic antidiuretic hormone-secreting gastric adenocarcinoma: a case report. Journal of Medical Case Reports 2014 8:185.

\section{Submit your next manuscript to BioMed Central and take full advantage of:}

- Convenient online submission

- Thorough peer review

- No space constraints or color figure charges

- Immediate publication on acceptance

- Inclusion in PubMed, CAS, Scopus and Google Scholar

- Research which is freely available for redistribution 